\title{
THE EFFECT OF CAREER DEVELOPMENT, WORK MOTIVATION, AND JOB SATISFACTION ON EMPLOYEE PERFORMANCE
}

\author{
Januari Wau ${ }^{* 1}$ and Purwanto*) \\ *) Master of Management Study Program, Universitas Esa Unggul \\ Jl. Arjuna Utara No.9, Kebon Jeruk, Jakarta 11510, Indonesia
}

\begin{abstract}
This research aims to determine the effect of career development, work motivation, and job satisfaction on employee performance. In principle, human resources are one of the important factors in companies to achieve their goals. In this case, the researcher focuses on the job satisfaction variable as a mediating variable, including linking career development and work motivation to employee performance. Good career development, good motivation, and good job satisfaction can improve the results of employee performance in achieving company progress. In this research, the population was employees at MNC Studios company. The sample consisted of 265 people using a saturated sample. Data analysis used validity test, reliability test, Kaiser-Msyer-Olkin measures of sampling (KMO), and Measures of Sampling Adequacy (MSA). Data were analyzed using the Structural Equation Model (SEM) using Lisrel. Based on the result of testing the differences of coefficients on the research model, it showed that career development had a positive effect on employee performance and job satisfaction, job satisfaction had a positive effect on employee performance, and work motivation had a positive effect on job satisfaction and employee performance.
\end{abstract}

Keywords: career development, work motivation, job satisfaction, employee performance

\begin{abstract}
Abstrak: Tujuan penelitian ini mengetahui pengaruh pengembangan karir, motivasi kerja, dan kepuasan kerja terhadap kinerja pegawai. Dimana sumber daya manusia merupakan salah satu faktor penting untuk tercapainya tujuan perusahaan. Dalam Hal ini, peneliti mengangkat variabel kepuasan kerja sebagai variabel mediasi, diantaranya menghubungkan pengembangan karir dan motivasi kerja terhadap kinerja pegawai, dimana pengembangan karir yang baik, motivasi yang baik dan kepuasan kerja yang baik dapat meningkatkan hasil kinerja karyawan yang baik untuk memperoleh kemajuan perusahaan. Dalam penelitian ini populasi yang diteliti adalah karyawan perusahaan di MNC Studios. Sampel dalam penelitian berjumlah 265 orang dengan sampel jenuh. Analisis data dalam penelitian ini menggunakan uji validitas, uji reliabilitas, Kaiser-Msyer-Olkin measure of sampling (KMO) dan measures of sampling adequacy (MSA). Data dianalisis dengan menggunakan Structural Equation Model (SEM) Lisrel. Berdasarkan hasil pengujian selisih koefisien terhadap model penelitian. Pengembangan karir berpengaruh positif terhadap kinerja pegawai. Pengembangan karir berpengaruh positif terhadap kepuasan kerja. kepuasan kerja berpengaruh positif terhadap kinerja pegawai. Motivasi kerja berpengaruh positif terhadap kepuasan kerja. Motivasi kerja berpengaruh kinerja pegawai. Motivasi kerja berpengaruh positif terhadap kepuasan kerja.
\end{abstract}

Kata kunci: pengembangan karir, motivasi kerja, kepuasan kerja, kinerja pegawai

\footnotetext{
${ }^{1}$ Alamat Korespondensi:

Email: januari29.wau@gmail.com
} 


\section{INTRODUCTION}

According to Haryani (2013), the key to improve performance is about how the organization can develop the Human Resources (HR). The task of the development program in the Human Resource department to create improvement and reliable organizational functions are difficult. Therefore, every company always strives to have qualified human resources, because without them a company will not run well. Both human resources and the company must have a mutualistic relationship, the company needs qualified employees, while employees need the company to fulfill their needs (Parimita et al. 2015). Employees at MNC Studios need to improve their work performance. They must be able to know the factors that can affect work performance including job satisfaction, work motivation, and career development which must be possessed by everyone at work. A high level of job satisfaction will affect someone in completing his work. Thus, the company's goals can be achieved properly. Otherwise, the low job satisfaction of employees in a company will reduce the effectiveness and efficiency of their work so that the company's goals can not be achieved properly. Employee involvement is a concept that is considered as an important element to succeed in the business (Satisfaction, 2015).

Currently, research on work performance issue is very crucial to be examined. MNC Studios is a company run in a media industry so that it requires creative workers to provide an informative, interesting, and qualified television programs. Those requirements are needed to attract public interest and reach a high television rating. For these reasons, the researcher wants to ensure that employees working at MNC studios have appropriate performance, high job satisfaction and work motivation, and their respective career development. As stated by Sunyoto (2012), job satisfaction can be felt directly by the employees because the company facilitates them in terms of good workspace, appropriate workload, and flexible work time. This makes a person's work motivation increases because the desired needs are achieved. Besides, it can support career development for every employee as self-readiness in using career opportunities by increasing employee performance and productivity and reducing labor turn over.

Work performance is a very important thing in a company to achieve its goals. Employee performance is one of the very dominant factors in improving company performance. The work performance that can be achieved by a person or group of people in an organization is appropriate with their respective authorities and responsibilities as an effort to achieve the organization's goals legally without violating the rule and based on morals, and ethics. By increasing employee performance, the company's goals will be more easily achieved. According to Mathis \& Jackson (2012); Dianti et al. (2017); Anthony \& Weide (2015), three main factors affect work performance which are capability factors, including talent, interest, personality factors; efforts such as motivation, work ethic, attendance, task design; and organizational support, such as training and development, equipment and technology, performance standards, as well as management and coworkers.

Job satisfaction refers to an individual's general attitude and each individual has a different level of satisfaction. Job satisfaction also has consequences for the work performance of employees. The research related to the relationship between employees and their organizations has increased rapidly and another research is the concept of employee involvement in their work (Bakker \& Leiter, (2010); Rothbard \& Patil, (2012); (Satisfaction, 2015)). Job satisfaction will be achieved if the organization can drive strong motivation to achieve better performance (Evanda, 2017). An employee tends to work enthusiastically if they are satisfied with their work. However, job satisfaction of employees is a key driver of morale, discipline, and employee work performance in realizing the company aims. Sopiah, (2013) describes job satisfaction as an emotional response regarding job situations and conditions. Moreover, Wibowo (2015) and Evanda (2017) state job satisfaction as someone's level of happiness that is associated with a positive assessment of their work and workplace. High job satisfaction will reduce the level of employees' absence. Mangkunegara (2015) says that career development is an employment activity that helps employees plan their future careers in the company so that both the company and employees can develop themselves optimally.

It also cannot be separated from motivating so that the workers can give the best contribution to the company. This is in line with the research findings of Rinto and Syah (2018), they state that motivation affects employee performance. Samsudin (2015) states that a sense of motivation as a process of influencing or encouraging from outside towards a person or working group to carry out something that has been set. Concerning 
human resources, work motivation is a very important thing because it will affect the success or failure of an organization Ali and Syah, (2019); Amalia, (2018). As stated by Mangkunegara (2015), motivation is a condition that encourages people towards a particular goal. Therefore, in an organization, a manager must be able to give encouragement and enthusiasm to his employees so that employees feel motivated, valued, and more professional. This certainly has a good effect on the organization (Alianto and Anindita, 2017). If the employee has been given good motivation, the employee will show their totality in the organization. According to Smith et al. (1969) in Luthans (2015), there are several dimensions of job satisfaction to reveal important characteristics of a job that people can respond to. The first dimension is to work itself. Career development is also one factor that can affect employee performance. Cianni \& Wnuck (1997) in Wibowo (2012) state that companies that have a systematic model in the career development of their employees will have good performance. Performance Appraisal (PA) is a major contributor to the performance and effectiveness of the organization (Aguinis, 2013; Ismail \& Rishani, 2018). The research finding is supported by Applebaum et al. (2011); Faraz and Indartono (2018), they state that companies that have good career management will increase the willingness of employees to participate in development activities and to behave in conducting development so that it will improve their performance. In this case, the researcher focuses on the job satisfaction variable as a mediating variable, including linking career development and work motivation to employee performance. On the other hand, from the previous research, it was found that there was no one has researched four variables with the title the influence of career development, work motivation, job satisfaction on employee performance. Besides, the research gap from the previous research is that research was conducted on some private television companies in Indonesia. From the background knowledge above purpose career development, work motivation, and job satisfaction are very important to measure employee performance. Thus, the title of the research is, "The Effect of Career Development, Work Motivation, and Job Satisfaction on Employee Performance (Case Study on Companies in MNC Studios)".

\section{METHODS}

In this research, the population was company's employees at MNC Studios consisting of several units (RCTI, MNCTv, GlobalTv, MNC Channel, MNC Picture), located at Jalan Raya Perjuangan, No. 1, West Jakarta. The variables were exogenous variables, namely career development, and work motivation, and endogenous variables, namely job satisfaction and performance. The time of the research was carried out from February to April 2020.This research used a deductive research approach. Data collection was carried out by distributing questionnaires to the employees of PT. Rajawali Citra Televisi Indonesia, West Jakarta. Furthermore, the sampling was appropriate with SEM Lisrell, in which there were at least 5 times the number of questionnaires (Hair et al. 2014). The number of questionnaire statements was 53 statements, thus the number of samples taken in this research was $(53 \times 5)$ 265 respondents.

According to Hair et al. (2014), (SEM) Lisrell a multivariate statistical analysis technique that combines aspects in multiple regression (which aims to test the dependent relationship) and factor analysis (which presents unmeasured concepts factors with multiple variables) that can be used to estimate a series of dependent relationships that influence each other simultaneously. Furthermore, this study used factor analysis to test the validity by looking at the values of Kaiser-Msyer-Olkin (KMO) and Measures of Sampling Adequacy (MSA). KMO and MSA value that can be accepted is a minimum value of 0.5 . While the reliability test is a value of alpha Cronbach $>0.6$, which means reliable (Malhotra, 2014).

Measurements in this research used the career development variable adopted from $\mathrm{Li}$ et al. (2014) consisting of 18 questions and the motivation variable adopted Sukmasari (2016) consisting of 6 questions, the work satisfaction variable adopted Vandenabeele (2009) in Inuwa (2016) consisting of 6 questions, and the work performance variable adopted from Rosady and Syah (2018) consisting of 13 questions. In this research, the data obtained by using a questionnaire, while the measurement scale obtained by using the Likert scale method. The Likert scale used five alternative answers (Sugiyono, 2012). The hypothesis testing proposed based on testing the research model (Figure 1) is as follows: 
$\mathrm{H}_{1}$ : Appropriate career development will improve employee performance

$\mathrm{H}_{2}$ : Appropriate career development will increase job satisfaction

$\mathrm{H}_{3}$ : High job satisfaction will improve employee performance

$\mathrm{H}_{4}$ : High work motivation will increase job satisfaction

$\mathrm{H}_{5}$ : High job satisfaction will improve employee performance

\section{RESULTS}

\section{Analysis of Validity Test and Reliability (Pretest)}

The validity test in this research used factor analysis by looking at the value of Kaiser-Msyer-Olkin measure of sampling (KMO) and Measures of Sampling Adequacy (MSA) that must be $>0.500$ with 1 component matrix (Malhotra, 2014). The validity test result of the career development variable consisting of 18 questions was valid. The results of the validity test of the work motivation variable consisting of 16 questions showed that not all questions were valid, which is in MK3 (0.450) and MK4 (0.476). Moreover, the result of the validity test of the job satisfaction variable consisting of 6 questions was valid as well as the result of the validity test of the employee performance variable consisting of 13 questions was valid. Furthermore, the reliability test of all questions regarding the variable of career development, job satisfaction, and employee performance showed that the value of alpha Cronbach $>0,6$, which means reliable (Malhotra, 2014).

\section{Analysis of the Demographic Differences on Respondents}

Analysis of respondents' demographic differences in this research includes gender, age, education level, monthly income, and length of work to find out a difference in each variable (career development, motivation, job satisfaction, and employee performance). Thus, it is necessary to conduct a different test with ANOVA. If the value of sig homogeneity is $>0.05$ and ANOVA is $<0.05$, it means that there is a difference in the homogeneity. Meanwhile, if the value of sig homogeneity is $>0.05$ and ANOVA is $>0.05$, it means that there is no difference in the homogeneity. Also, if the value of sig homogeneity is $\leq 0.05$, it means that ANOVA is not tested or the results are not in the test (not homogeneity). The results of this study indicate that almost all respondents have the same answer. In other words, the answer is homogeneous. Regarding respondents' answers, the researcher then conducted an ANOVA test based on gender, age, length of work, monthly income on career development variables, motivation, job satisfaction, and employee performance, and respondents' answers based on the last education on career development variables. In response, respondents' answers based on last education to career development variables showed a non tested result (sig homogeneity $\leq 0.05$ ). Moreover, respondents' answers based on the last education on motivation variables, job satisfaction, and employee performance showed a discrepancy that the respondent's response was homogeneity and ANOVA test can be conducted.

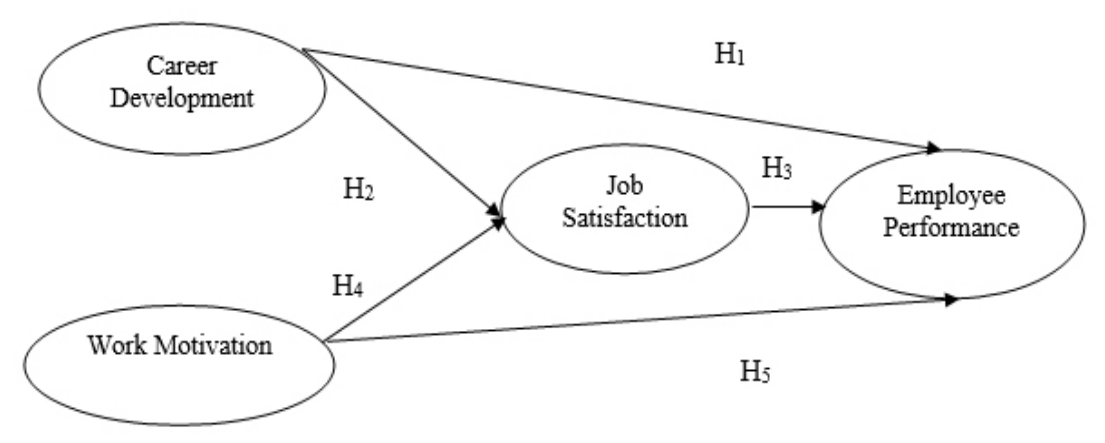

Figure 1. Research model 


\section{The Test Validity and Reability of Construction}

Based on the recommendation of Hair et al. (2014), the result of the measurement of the construct validity can be accepted, where all indicators on career development variables consist of two dimensions (perception of the value of Career development and perception of availability of Career Development Opportunities), work motivation variables covers three dimensions (need for achievement, need for affiliation and need for power). Then, job satisfaction variables and performance variables include five dimensions (work results quality, speed and accuracy, initiatives, skills, and good communication). They reached a good match for factor loading $(>0.50)$, and the T-value was greater than T-table (1.96) at a level of significance 5\%. Furthermore, the construct reliability test meets the reliability requirements with $C R$ values was above 0.60 and VE values were above 0.50 (Hair et al. 2013). At $\mathrm{CR}$ values all variables meet the reliability requirement of the value above was 0.60 for career development variables $(0.91)$, work motivation (0.94), job satisfaction (0.94), and performance (0.96). In the VE value, all qualified reliability was the value above 0.50 for career development variables $(0.84)$, work motivation $(0.85)$, job satisfaction (0.74), and performance (0.83).

\section{Structural Test Analysis}

The first analysis explained that careerdevelopment(PK) and work motivation (MK) variables simultaneously affect job satisfaction (KK) with an $\mathrm{R}^{2}$ value of of0.68. It can be said that career development (PK) and work motivation (MK) variables can explain $68 \%$ variants of job satisfaction (KK) while the remaining $32 \%$ of the total amount can be explained by other variables that do not exist in this research. The second analysis is job satisfaction (KK), career development (PK) and work motivation (MK) variable simultaneously affect employees' performance (KP) with an $\mathrm{R}^{2}$ value of 0.33 . It can be said that job satisfaction (KK), career development (PK), and work motivation (MK) variable can explain 33\% variant of employee performance (KP), while the remaining $67 \%$ of the total amount can be explained by other variables that do not exist in this research.

\section{The Analysis of Model Conformity Test}

From the analysis of the all conformity model on group 1 to 7 , all tests showed good matches, including Fit
Index, Critical N, the goodness of Fit, Chi-Square, ECVI, AIC, and CAIC, whereas RMSEA show close fit. Based on the Path Diagram T-value above (Figure 2 ) it can be concluded that all the proposed hypotheses support previous research with the provisions of T-Value $>1.96$. For more details, it can be seen in the discussion of the following hypothesis:

\section{Appropriate Career Development Will Improve Employee Performance}

The finding showed that the results of the analysis support the hypothesis of $\mathrm{H}_{1}$ that the appropriate career development will improve employee performance. This can be interpreted that appropriate career development for employees at MNC Studios can improve employee performance and productivity, decrease labor turn over, and will increase opportunities for employees' promotion. For employees, career planning can encourage their readiness to use the available career opportunities. Especially for the human resources department, it will facilitate the fulfillment of the organization's internal personnel development needs. An employee plays a role to create his career planning. The employees are responsible to keep improving their skills to keep up their competencies based on what a company's needs. Act proactively to see the opportunities that exist, and the possibility of problems arise in their current career. This is in line with the research findings of Saluy and Kemalasari (2017); Wiyani and Rahardjo (2015); Dewi and Utama (2016) which concluded that career development has an effect on employees' performance. Based on the results of testing the differences of coefficients in the research model career development has a direct effect on employees' performance.

\section{Appropriate Career Development Will Increase Job Satisfaction}

Thefinding showed that the results of the analysis support the hypothesis of $\mathrm{H}_{2}$ state that the appropriate career development will improve employee performance. This shows that the company at MNC Studios can provide satisfaction to its employees. Job satisfaction is the main point that needs to be considered in the company because without job satisfaction the employee's work productivity will decrease. With a good career development, employees will feel motivated to create a sense of satisfaction in carrying out the work. The existence of a career development program can increase 
employees' encouragement to be more outstanding and provide maximum contribution to the company. This happens because an employee's job satisfaction will arise if the career development existing in a company already clearly to be implemented. Career development is expected to achieve optimal employee satisfaction. This is in line with the research findings of Shujaat et al. (2013); Anwar and Shukur (2015); Lasut et al. (2018) which state that career development gives effect on job satisfaction. Based on the results of testing the differences in coefficients in the research model, it showed that career development had a direct effect on employees' performance.

\section{High Job Satisfaction Will Improve Employee Performance}

The finding showed that the analysis result supports the hypothesis of $\mathrm{H}_{3}$, which is high job satisfaction will improve employees' performance. This shows that job satisfaction at MNC Studio can improve employees' performance. If employees' satisfaction in the form of desires, hopes, goals, and needs of these employees is met, it will improve performance in the company. Vice versa, if job satisfaction is not fulfilled then the performance will decrease. Employees who get job satisfaction will work better, so it will have an effect on the performance of their employees. Employees' performance results are expected to increase company profits. Efforts to improve employee performance cannot be arranged in detail and directed because increased performance can be influenced by job satisfaction for each individual or group. This is consistent with the research findings of Sidabutar, Syah, and Anindita (2020); Ngarm and Siengthai (2017); Inuwa (2016); Adigun, Oyekunle dan Onifade (2017) which concluded that job satisfaction affects employee performance. Based on the results of testing the differences in coefficient in the research model, it was seen that career development had a direct effect on employees' performance.

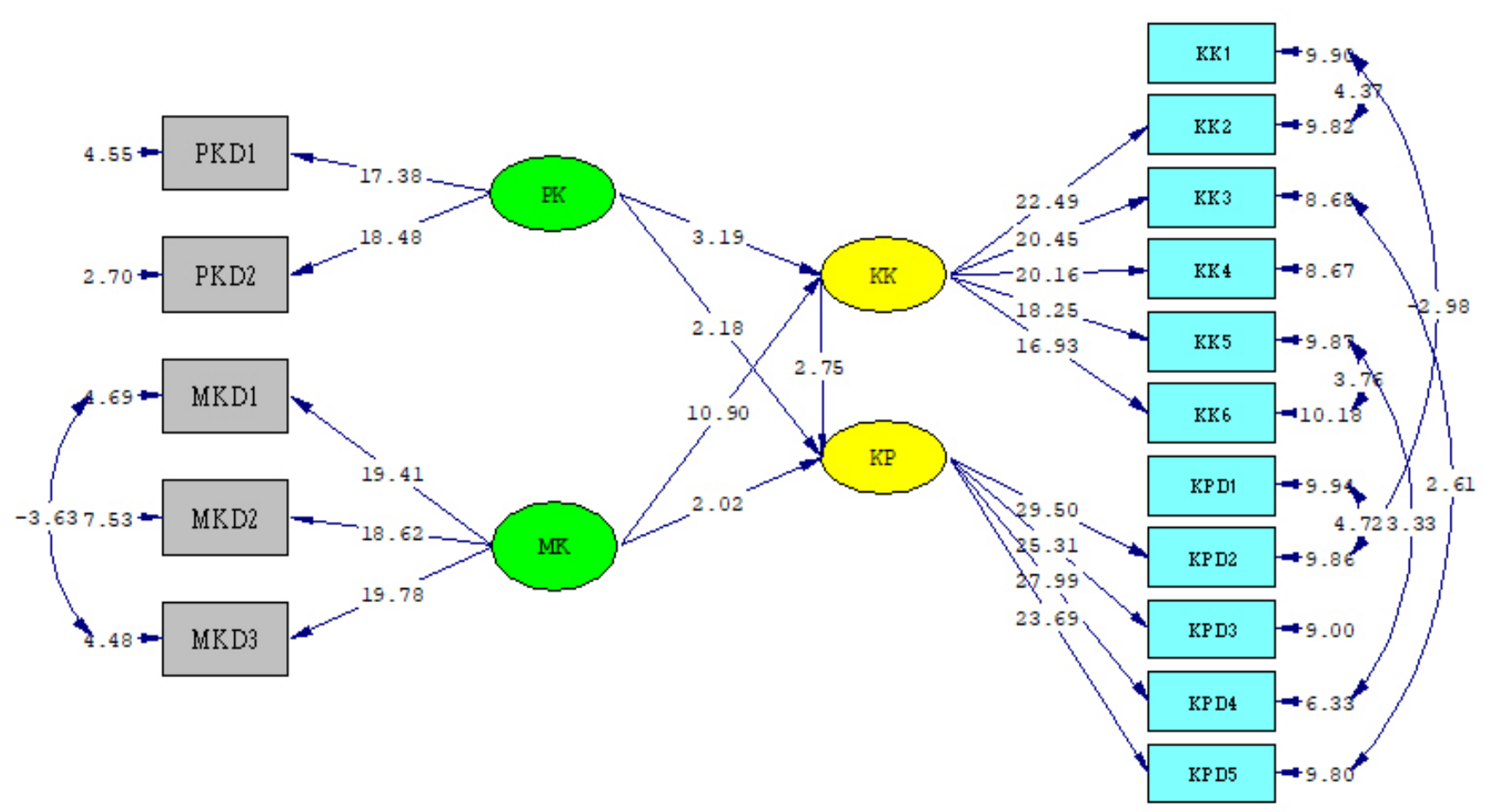

Chi-Square=139.13, df $=87, \mathrm{P}$-value $=0.00033, \mathrm{RMSEA}=0.048$

Figure 2. T-Value Path Diagram 


\section{High Work Motivation Will Increase Job Satisfaction}

The finding showed that the analysis result supports the hypothesis of $\mathrm{H}_{4}$ which says that the high work motivation will increase job satisfaction. Concerning the job satisfaction, the role of motivation is very important to drive and improve employees' work for obtaining job satisfaction because employees' expectations can be achieved through it. As revealed by Sekartini (2016), motivation arises because of a need, and for this reason, it leads to achieving specific goals. If the goal has been achieved, job satisfaction will be received, which Miner (2008) says that job satisfaction is a factor that encourages employees to work harder as well as becomes motivation in working. Therefore, it is in accordance with the research findings of Sohail et al. (2014); Ali et al. (2016); Lasut et al. (2018) which concluded that work motivation influence job satisfaction. Based on the results of testing the differences in the coefficients in the research model, career development had a direct effect on employees' performance.

\section{High Job Satisfaction Will Improve Employee Performance}

The finding showed that the results of the analysis support the hypothesis of $\mathrm{H}_{5}$ that is high job satisfaction will improve employee performance. Manpower in a company has an important role and function in achieving company goals. Employees with good performance are those who have high work motivation, complete the tasks given on time, always contribute, and have a good attitude and behavior according to work standards, either by the organization or the work values applied in the work environment. Performance can be influenced by two factors, namely internal factors, and external factors. Internal factors are factors that come from employees. While external factors are supporting factors for employees that come from the work environment, for example, career development. As revealed by Gibson (2008), one that affects employee performance is employee work motivation. Furthermore, these results are strengthened by the research findings of Muogbo (2013); Wiyani \& Rahardjo (2015); Ali et al. (2016); Amalia and Marpaung (2019); Nastohar and Anindita (2019) state work motivation influences employee performance. Based on the results of testing the differences in the coefficients in the research model, career development had a direct effect on employee performance.

\section{Managerial Implications}

When viewed from the results of statistical data, employee performance is largely determined by motivation and job satisfaction. So that the existence of high motivation and job satisfaction can improve employee performance at the MNC Studios company. This research is expected to provide various benefits for the parties involved, including MNC Studios (RCTI, MNCTv, GlobalTv, MNC Channel, MNC Picture), located on the Jalan Raya Perjuanan No. 1 West Jakarta. The identification of various obstacles/problems faced by the company can be used as a material reference for further improvement and the development of career, work motivation, job satisfaction, and employee performance in the company.

\section{CONCLUSIONS AND RECOMMENDATIONS}

\section{Conclusions}

Career development had a positive effect on employees' performance, career development had a positive effect on job satisfaction, job satisfaction had a positive effect on employees' performance. Work motivation had a positive effect on job satisfaction, and work motivation had a positive effect on employees' performance. Mediation analysis showed that job satisfaction could mediate three variables, namely career development, work motivation, and employee performance.

\section{Recommendations}

For further research are: Add other variables to measure job satisfaction and employee performance for employees at MNC Studios or other research objects. The number of samples is expanded. Another suggestion is to use other research methods to get more varied information, and limitations of this study include: This research was only conducted on company employees at MNC Studios, which consisted of RCTI, MNCTv, GlobalTV, MNC Channel, and MNC Pictures, located on Jalan Raya Perjuangan No. 1. West Jakarta. Then, the research subject only discusses four variables, namely career development, work motivation, job satisfaction, and employee performance. The survey filled out by respondents is likely not based on the real conditions, but based on their ideal conditions expected. 


\section{REFERENCES}

Adigun AO, Oyekunle IA, Onifade TA. 2017. Influence of job satisfaction on employees Performance in MTN Nigeria. Global Journal of Human Resource Management 5(1):54-60.

Aguinis H. 2013. Performance Management. New Jersey: Pearson Prentice Hall.

Ali A, Bin L, Piang H, Ali, Z. 2016. The impact of motivation on the employee performance and job satisfaction in it park (software house) sector of Peshawar, Pakistan. International Journal of Academic Research in Business and Social Sciences 6(9):297-310.

Alianto A, Anindita R. 2017. Pengaruh kompensasi dan work life balance terhadap kepuasan kerja dimediasi stres kerja. Jurnal Universitas Esa Unggul 1-17.

Ali SC, Syah TYR. 2019. Organizational culture and motivation over mediated performance by organizational commitment. Journal of Multidisciplinary Academic 3(4):85-90.

Amalia L. 2018. Model motivasi kerja dan komitmen organisasional sebagai konsekuensi dari keterlibatan kerja karyawan non dosen PTS di DKI Jakarta. Forum Ilmiah 15(1):30-35.

Amalia L, Marpaung RR. 2019. The impact of work culture, competence and motivation on the performance of permanent employees in telaga hikmah palm oil mill (Sampoerna Agro Group Business Unit). Advances in Economics, Business and Management Research 100.

Amstrong M, Baron F. 2016. Manajemen Kinerja. Jakarta: Erlangga.

Anthony PJ, \& Weide J. 2015. Motivation and careerdevelopment training programs: use of regulatory focus to determine program effectiveness. Higher Learning Research Communications 5(2):24.

Anwar G, Shukur, I. 2015. The impact of training and development on job satisfaction: a case study of private banks in Erbil. International Journal of Social Sciences \& Educational Studies 2(1):6572.

Applebaum HS, Ayre H, Shapiro B. 2001. Career management in information technology: a case study. Career Development International 7(3):142-158.

Bahri S, Nisa Y. 2017. Pengaruh pengembangan karir dan motivasi kerja terhadap kepuasan kerja karyawan. Jurnal Ilmiah Manajemen Dan Bisnis 18(1):9-15.
Bakker A. Leiter M. 2010. Work Engagement: A Handbook of. Essential Theory and Research. New York:Psychology Press.

Cianni, Wnuck. 1997. Individual growth and team enhancement: moving toward a new model of career developmen. Academy of Management Excecutive 11(1):105-116.

Dewi NLPA, Utama IWM. 2016. Pengaruh pengembangan karier terhadap kinerja karyawan melalui mediasi motivasi kerja pada karya mas art gallery. E-Jurnal Manajemen Unud 5(9):5494-5523

Dharma S. 2012. Manajemen Kinerja Falsafah Teori dan Penerapannya. Yogyakarta: Pustaka Pelajar.

Dianti, Hubeis M, Affandi MJ. 2017. The Effect of Motivation of Work and Work Climate to Work Satisfaction and Implications to Performance Performance of Education Bogor Agricultural University. Jurnal Aplikasi Bisnis dan Manajemen 3(3):361-372.

Dubrin J. 1982. Personnel And Human Resources Management. California: Kent Publising Company.

Edison E, Anwar Y, Komariah I. 2016. Manajemen Sumber Daya Manusia. Bandung: Alfabeta.

Evanda R. 2017. Pengaruh motivasi, pengembangan karir terhadap kepuasan kerja dan kinerja perawat di Rumah Sakit dr.Soebandi Jember. Jurnal Bisnis Dan Manajemen 11(1):41-49.

Faraz NJ. 2018. The mediation of frequent job on the effect of job fit, job satisfaction, on performance. The Business and Management Review 9(4):290296.

Gibson M. 2008. Manajemen Sumber Daya Manusia. Jakarta: Erlangga.

Hair JF, Black WC, Babin BJ. 2014. Multivariate Data Analysis (7 ed.). New York: Pearson.

Haryani PY. 2013. Korelasi antara pengembangan karir dengan motivasi kerja dan keinginan pensiun dini. Jurnal Buletin Studi Ekonomi 18(2):183189.

Hasibuan M. 2016. Manajemen Sumber Daya Manusia. Jakarta: PT Bumi Aksara.

Inuwa M. 2016. Job satisfaction and employee performance: an empirical approach. The Millennium University Journal 1(1):90-103.

Ismail HN, Rishani M. 2018. The relationships among performance appraisal satisfaction, career development and creative behavior. The Journal of Developing Areas 52(3):109-124.

Kidd CA. 2006. An exploration of the impact of 
employeejobsatisfaction, affect, andperformance on organizational financial performance in the health care industry. Semantic Scholar 355-362.

Lasut D, Tewal B, Koleangan RA. 2018. The effect work motivation, career development and leadership on employee satisfaction at PT Bank Sulut Go. EMBA 6(4):2298-2307.

Li K, Tong C, Wong A. 2014. The impact of career development on employee commitment of parttime faculty (ptf) in hong kong's continuing professional development (CPD) Sector. British Journal of Education, Society \& Behavioural Science 4(1):52-73.

Luthans F. 2015. Organization Behavior. New York: McGraw Hill International.

Malhotra N. 2014. Basic Marketing Research. England: Pearson Education.

Mangkunegara A. 2015. Sumber Daya Manusia Perusahaan. Bandung: Remaja Rosdakarya.

Mathis RL. Jackson J. 2012. Manajemen Sumber Daya Manusia. Jakarta: Salemba Empat.

McClelland D. 1987. Human Motivation. New York: Cambridge University Press.

Miner. 2008. Organizational Behavior, Performance \& Productivity. New York: State University.

Mitchell T. 1978. People In Organization; Under Standing Their Behaviors. New York: Mc Graw Hill.

Mondy R. 2012. Manajemen Sumber Daya Manusia. Jakarta: Erlangga.

Muogbo U. 2013. The influence of motivation on employees performance: a study of some selected firms in Anambra State. International Journal of Arts and Humanities 2(3):134-151.

Nastohar, Anindita R. 2019. Transformation employee performance during leadership motivation effect over kansai prakarsa coatings company. Journal of Multidisciplinary Academic 1(1):27-30.

Nawawi. 2015. Manajemen Sumber Daya Manusia. Yogyakarta: Universitas Gadja Mada.

Parimita W, Wahda LA, Handaru A. 2015. Pengaruh pengembangan karir dan motivasi terhadap kepuasan kerja karyawan PT POS Indonesia. Jurnal Riset Manajemen Sains Indonesia 6(1):326-350.

Permatasari I. 2006. Pengaruh pengembangan karir terhadap kinerja karyawan (studi kasus di PT Telkom Malang). MODERENISASI 2(3):177191.

Pila-Ngarm P, Siengthai S. 2017. Job redesign and employee performance: the mediating effects of human capital investment and job satisfaction. Organization Development Journal 35(2):7999.

Prasetya B. 2019. Pengaruh Kepemimpinan Transaksional dan Kompensasi terhadap Kepuasan Kerja Karyawan Divisi Operasional Unit Sentra Kas pada PT Bank Negara Indonesia (PERSERO) Tbk. [Tesis]. Jakarta: Universitas Esa Unggul.

Rinto O, Syah, TYR. 2018. The influences of compensation and motivation towards the performance mediated by organizational commitment: study on hr \& ga employees in PT Gajah Tunggal Tbk, Inonesia. International Journal of Economics, Commerce and Management VI(4):786-804.

Rivai V. 2013. Manajemen Sumber Daya Manusia UntukPerusahaan Dari Teori Ke Praktek. Bandung:Rajagrafindo Persada.

Robbin S. 2015. Perilaku Organisasi. Jakarta: Salemba Empat.

Rosady S, Syah TYRS. 2018. Work satisfaction antecedents and consequences: ananalysis of transformational leadership style, communication and performance of the nurses (study on the Hospital Nurses in Indonesia). International Advanced Research Journal in Science, Engineering and Technology 5(9):59-65.

Rothbard NP, Patil SV. 2011. Being There: Work Engagement and Positive Organizational Scholarship.UK: Oxford University Press.

Sadler S, Badger B. 1998. The HR practitioner's perspective on continuing professional development. Human Resource Management Journal 8(4):66-75.

Saluy AB, Kemalasari N. 2017. The impact of compensation, career development and employee engagement towards employee performance. Saudi Journal of Business and Management Studies (SJBMS) 3(5):515-522.

Samsudin S. 2005. Manajemen Sumber Daya Manusia. Bandung: Pustaka Setia.

Satisfaction J. 2015. Impact of motivation, job satisfaction, work stress and work environment on job performance 1(1)-90-103.

Sekartini N. 2016. Pengaruh kemampuan kerja, disiplin kerja, motivasi kerja terhadap kepuasan kerja dan kinerja karyawan administrasi Universitas Warmadewa. Jurnal Ekonomi \& Bisnis 3.

Shujaat S, Sana S, Aftab F, Ahmed I. 2013. Impact of career development on employee satisfaction 
in private banking sector karachi. Journal of Management and Social Sciences 9(2):1-8.

Sidabutar E, Syah, TYR, Anindita R. The impact of compensation, motivation, and job satisfaction on employee performance. Journal of Multidisciplinary Academic 4(1):1-5.

Smith P, Kendall L, Hulin C. 1969. The Measurement of Satisfaction In Work and Retriment: A Strategy For The Study of Attitudes. Chicago: RndMcnally.

Sohail A, Safdar R, Saleem S, Ansar S, Azeem. 2014. Effect of work motivation and organizational commitment on job satisfaction: (a case of education industry in Pakistan). Global Journal of Management and Business Research14(6):22494588.

Sopiah. 2011. Perilaku Organisasi. Yogyakarta: ANDI.

Stone T. 2011. Manajemen Sumber Daya Manusia Dalam Organisasi Publik dan Bisnis. Bandung: Alfabeta.

Sugiyono. 2012. Metode Penelitian Kuantitatif, Kualitatif, dan $R \& D$. Bandung: Alfabeta.

Sukmasari A. 2016. Analisa Motivasi Kerja dan Komitmen Organisasional sebagai Konsekuensi dari Keterlibatan Kerja (Studi pada Pegawai Non
Dosen Universitas Esa Unggul) [Tesis]. Jakarta: Universitas Esa Unggul.

Sunyoto D. 2012. Manajemen Sumber Daya Manusia. Yogyakarta: CAPS.

Terry GR. 2012. Prinsip-Prinsip Manajemen. Jakarta: PT Bumi Aksara.

Umam K. 2012. Manajemen Organisasi. Bandung: Pustaka Setia.

Vandenabeele W. 2009. The mediating effect of job satisfaction and organizational commitment on self-reported performance: more robust evidence of the PSM-performance relationship. International Review of Administrative Sciences 75(1):11-34.

Wibowo. 2015. Perilaku Dalam Organisasi (Edisi Kedu). Jakarta: PT Raja Grafindo Persada.

Wibowo F. 2006. Analisis Pengaruh Peran Kepemimpinan dan Pengembangan Karir Terhadap Komitmen Organisasi dalam Meningkatkan Kinerja Karyawan (studi kasus: PT. Bank Maspion Indonesia Cabang Semarang) [Tesis]. Semarang:UNDIP.

Wiyani E. Rahardjo M. 2015. Analisis pengaruh motivasi kerja, pengembangan karir dan komitmen organisasional terhadap kinerja karyawan. Diponegoro Journal of Management 4(3):1-19. 